\title{
PENGEMBANGAN SNACK EKSTRUSI BERBASIS JAGUNG, KECAMBAH KACANG TUNGGAK DAN KECAMBAH KACANG KECIPIR DENGAN LINEAR PROGRAMMING
}

\section{Extruded Snack Development Based on Corn, Sprouted Black Eyed-Pea and Sprouted Winged Bean with Linear Programming}

\author{
Syifa Qolbiyah Nasir*, Harijono \\ Jurusan Teknologi Hasil Pertanian, FTP Universitas Brawijaya Malang \\ Jl.Veteran Malang 65145 \\ *Penulis Korespondensi, email: syifaqn@gmail.com
}

\begin{abstract}
ABSTRAK
Penyediaan pangan sumber kalori dan protein dapat dipenuhi dari sumber daya pangan lokal, termasuk untuk pemenuhan kebutuhan gizi harian anak usia 7-9 tahun. Kombinasi antara jagung, kecambah tunggak dan kecipir dapat diolah menjadi jenis snack berbentuk ekstrudat yang disukai mereka. Metode yang digunakan dalam penelitian ini adalah metode optimasi Linear Programming dengan batasan total bahan $100 \mathrm{~g}$, kacang tunggak $\geq 25 \%$, kacang kecipir $\leq 5 \%$, total kalori $\geq 370 \mathrm{kkal}$ dan total protein $\geq 14.70 \mathrm{~g}$. Formulasi jagung : kecambah tunggak : kecambah kecipir terbaik yang diperoleh yaitu 70:25:5. Hasil uji sifat kimia (nutrisi) ekstrudat formulasi kadar air $2.77 \%(\mathrm{~b} / \mathrm{b})$, protein $15.98 \%(\mathrm{~b} / \mathrm{b})$, lemak $3.41 \%(\mathrm{~b} / \mathrm{b})$, karbohidrat $76.43 \%$ (b/b), kadar abu $1.42 \%$ (b/b) dan kalori $386.01 \mathrm{kkal}$. Hasil uji sifat fisik ekstrudat formulasi yaitu derajat pengembangan $522.50 \%$, daya patah $16.37 \mathrm{~N} / \mathrm{m}$, IPA $0.03 \mathrm{~g} / \mathrm{ml}$, IKA $0.03 \mathrm{~g} / \mathrm{ml}$, dan warna dengan nilai $L$ 76.71, a 3.18, dan b 28.79. Uji Hedonik pada produk ekstrudat dengan skala 1-5 menunjukkan nilai warna 3.19 (kurang suka), aroma 3.42 (kurang suka), rasa 2.94 (kurang suka), tekstur 4.03 (suka) dan kerenyahan 4.16 (suka). Pengembangan produk ekstrudat ini dapat memenuhi $20 \%$ kebutuhan kalori dan 30\% kebutuhan protein harian anak usia 7-9 tahun, sehingga dapat menjadi alternatif snack sehat bagi anak usia sekolah.
\end{abstract}

Kata kunci: Linear Programming, Optimasi Formulasi, Snack Sehat

\begin{abstract}
Calorie and protein can be supplied from local food, including the fulfilment of daily nutrition needs for 7-9 years old children. The combination of these, can be processed into extrudate snack for them. The method used in this research is Linear Programming with some limitations, there are materials total is estimated to be $100 \mathrm{~g}$, germinated black eyed-pea $\geq 25 \%$, germinated wing bean $\leq 5 \%$, total of calorie $\geq 370 \mathrm{kkal}$ and total of protein $\geq 14.70 \mathrm{~g}$. The best formulation for corn:sprouted black eyed-pea:sprouted winged bean is 70:25:5. Chemical characteristic showed water content $2.77 \%(w / w)$, protein $15.98 \%(w / w)$, fat $3.41 \%(w / w)$, carbohydrate $76.43 \%(\mathrm{w} / \mathrm{w})$, ash content $1.42 \%(\mathrm{w} / \mathrm{w})$ and calorie $386.01 \mathrm{kkal}$. Physical characteristic showed expansion ratio $522.50 \%$, hardness $16.37 \mathrm{~N} / \mathrm{m}$, WAl $0.03 \mathrm{~g} / \mathrm{ml}$, WSI 0.03 $\mathrm{g} / \mathrm{ml}$, and color value $L 76.71$, a 3.18, and $b 28.79$. Hedonic test with 1-5 scoring method showed value for color 3.19 (less liked), aroma 3.42 (less liked), flavor 2.94 (less liked), texture 4.03 (liked) dan crispiness 4.16 (liked). Development of this extrusion product can supply $20 \%$ of calorie and $30 \%$ of protein daily needs for 7-9 years old children, therefore it can be an alternative of healthy snack for 7-9 years old children.
\end{abstract}

Keywords: Linear Programming, Formulation optimation, Healthy Snack 
Pengembangan Snack Ekstrusi Berbasis Jagung - Nasir, dkk Jurnal Pangan dan Agroindustri Vol.6 No.2: 74-85, April 2018

\section{PENDAHULUAN}

Indonesia merupakan negara yang kaya akan sumber daya alam (SDA) yang melimpah, terutama bagi sumber daya pangan. Komoditas pangan lokal sekunder seperti serealia, kacangkacangan dan umbi-umbian sering dianggap inferior, terlepas dari kandungan gizinya yang baik. Penerapan teknologi pengolahan pangan seperti teknologi ekstrusi menjadi alternatif penting untuk mengangkat nilai komoditas pangan lokal di Indonesia.

Berbagai pangan olahan seperti kudapan (snack) berbahan baku pangan impor banyak diminati karena bentuk dan cita rasanya yang menarik terutama bagi anak usia awal sekolah usia 7-9 tahun, salah satunya adalah snack ekstrudat. Teknologi pengolahan ekstrusi merupakan teknologi yang efisien dalam segi pengolahan pangan (Anton, et al., 2009). Hal ini dikarenakan adanya kombinasi dari beberapa proses meliputi pencampuran, pemasakan, pengadonan, penghancuran, pencetakan, dan pembentukan (Estiasih dan Ahmadi, 2009). Selain itu, pengolahan ekstrusi juga dapat menghasilkan produk dengan bentuk, warna dan citarasa yang bervariasi tergantung pada bahan baku dan kondisi pengolahan yang digunakan (Estiasih dan Ahmadi, 2009).

Bahan baku yang digunakan untuk ekstrusi umumnya tinggi pati seperti biji sereal dengan kandungan air sekitar 14-15\% dan diproses menjadi produk yang mengembang secara maksimal (Moscicki, 2011). Jagung yang mempunyai rasio amilosa terhadap amilopektin sebesar 22:78 sesuai untuk produk ekstrusi (Koswara, 2009). Kurangnya kandungan protein pada jagung dapat diatasi dengan menambahkan kacang-kacangan seperti biji kecipir dan kacang tunggak. Kandungan protein kecipir (29.65\%) dan tunggak $(23.85 \%)$ merupakan yang tertinggi dibandingkan jenis kacang-kacangan lainnya (USDA, 2016). Kandungan asam amino pada kacang tunggak yang rendah akan asam amino threonine, alanine, glisin dan prolin (Prakash, et al., 1987) dapat ditambahkan dari tingginya kandungan asam amino tersebut pada kacang kecipir. Selain itu, rendahnya kandungan asam amino metionin pada kacang kecipir (Husain dan Bahasy, 1998) juga dapat ditambahkan dari kacang tunggak yang cukup tinggi kandungan asam amino metionin. Hal ini menjadikan dua jenis kacang-kacangan ini merupakan bahan yang komplementer. Perkecambahan terbatas pada kacang-kacangan dapat mengurangi zat anti gizi dan meningkatkan daya cerna protein (Khairi dan Kanetro, 2014). Pada proses ekstruksi yang menggunakan tipe single screw umumnya digunakan bahan baku dengan ukuran tertentu dan seragam (grits) sehingga untuk biji-bijian perlu dilakukan pengecilan ukuran terlebih dahulu (Moscicki, 2011).

Snack ekstrudat dengan kandungan kalori dan protein tertentu perlu diformulasikan sebelum proses. Salah satu cara optimasi formula makanan dengan kandungan gizi yang dikehendaki adalah dengan linear programming. Metode ini menggunakan aplikasi model matematis yang didahului dengan penelitian eksperimental sederhana untuk menentukan (i) batasan kandungan zat gizi produk yang dituju dan (ii) mengetahui kandungan gizi bahan-bahan yang akan digunakan (iii) menetapkan batasan maksimal atau minimal jumlah bahan tertentu yang digunakan untuk membuat formula. Penggunaan linear programming telah banyak digunakan pada formulasi makanan pendamping ASI (MP-ASI) (Ismayanti, 2014), food bars (Nurmasita, 2014), dan bagiak (Putri, 2015). Berdasarkan Peraturan Menteri Kesehatan Republik Indonesia No. 75 Tahun 2013, anak-anak usia 7-9 tahun membutuhkan asupan $1850 \mathrm{kkal}$ dan 49 gram protein per hari. Kekurangan asupan kalori dan protein serta zat gizi lainnya diharapkan dapat diperoleh dari makanan lain yang dikonsumsi anak setiap hari. Oleh karenanya penerapan linear programming juga sangat dimungkinkan untuk pengembangan formula snack ekstrusi anak-anak usia 7-9 tahun, untuk menyediakan minimal sebesar 20\% kebutuhan kalori dan 30\% kebutuhan protein dari angka kecukupan gizi (AKG). 


\title{
BAHAN DAN METODE
}

\begin{abstract}
Alat
Alat yang digunakan dalam penelitian ini adalah mesin pengering tipe kabinet, mesin penepung (disc mill), ekstruder ulir tunggal, timbangan analitik (merk memmert). Peralatan yang digunakan untuk analisis adalah oven listrik (merk WTC Binder), furnace (merk Thermolyne 47900), soxhlet (merek Gerhardt), timbangan analitik (merek Denver M310 dan Toledo ML54), distilator, tensil strength (merek Imada ZP200N), dan lemari asam.
\end{abstract}

\section{Bahan}

Bahan yang digunakan pada penelitian ini adalah jagung dan kacang tunggak yang diperoleh di Pasar Dinoyo Malang, kacang kecipir yang diperoleh di Toko Pertanian Subur, Yogyakarta. Sedangkan bahan analisis yang digunakan yaitu aquades, $\mathrm{H}_{2} \mathrm{SO}_{4}(\mathrm{pa})$, indikator $\mathrm{MM}$ dan $\mathrm{PP}$, tablet Kjeldahl, petroleum eter (pa), $\mathrm{HCl} 0.10 \mathrm{~N}$ (teknis), $\mathrm{NaOH} \mathrm{45 \%} \mathrm{(teknis)} \mathrm{yang} \mathrm{diperoleh} \mathrm{di}$ toko Makmur Sejati dan Kridatama.

\section{Metode Penelitian}

Penelitian ini dilakukan dengan menggunakan metode optimasi Linear Program berupa aplikasi model matematis yang didahului dengan penelitian eksperimental sederhana sebagai penelitian pendahuluan untuk menentukan batas-batas jumlah bahan yang digunakan (minimal dan maksimal). Model matematis selanjutnya dimasukkan ke dalam aplikasi solver pada Microsoft Excel 2010 untuk memperoleh formulasi terbaik. Hasil tersebut kemudian diverifikasi dan divalidasi untuk selanjutnya diimplementasikan menjadi produk akhir.

\section{Tahapan Penelitian}

\section{Pembuatan Grits Kecambah Kacang Tunggak dan Kacang Kecipir (modifikasi Rahardian, 2015)}

Kacang tunggak dan kacang kecipir disortasi dan dicuci, kemudian direndam selana 12 jam (kacang tunggak) dan 48 jam (kacang kecipir). Selanjutnya ditiriskan dan dikecambahkan selama 24 jam (kacang tunggak dan kacang kecipir). Setelah itu dilakukan pengeringan $60^{\circ} \mathrm{C}$ selama 6 jam. Untuk kacang tunggak dilakukan pengupasan kulit terlebih dahulu sebelum dikeringkan. Terakhir dilakukan penghancuran kasar dengan menggunakan disk mill sampai menghasilkan ukuran grits.

\section{Pembuatan Snack Ekstrudat (modifikasi Utami, 2014)}

Bahan baku yang telah dipersiapkan berupa grits jagung, grits kecambah kacang tunggak tanpa kulit dan grits kecambah kacang kecipir dicampurkan sesuai dengan formulasi solusi dari program linear dan dimasukkan ke dalam ekstruder single screw suhu $100^{\circ}-200^{\circ} \mathrm{C}$ hingga diperoleh produk akhir ekstrudat.

\section{Analisis Kimia}

Produk ekstrudat formalasi dilakukan uji proksimat meliputi uji kadar air metode oven (AOAC, 1995), uji kadar protein metode Kjeldahl, uji kadar karbohidrat metode by difference, uji kadar lemak metode soxhlet (AOAC,1995), uji kadar abu, dan perhitungan total kalori dimana tiap satu gram protein, lemak, dan karbohidrat diberi nilai kalori masing-masing sebesar $4 \mathrm{kkal} / \mathrm{g}, 9 \mathrm{kkal} / \mathrm{g}$, dan $4 \mathrm{kkal} / \mathrm{g}$ secara berurutan. 


\section{Analisis Fisik}

Produk ekstrudat formulasi dilakukan uji warna dengan color reader, uji kekerasan produk dengan alat tensil strength, uji derajat pengembangan (Zullichen, 1975, dalam Linko et al., 1981), uji indeks penyerapan air (IPA) dan uji indeks kelarutan air (IKA).

\section{Analisis Organoleptik}

Produk ekstrudat formulasi dibandingkan dengan produk sejenis yang ada dipasaran, yaitu merek Oishi dan Momogi rasa jagung bakar. Ekstrudat formulasi juga diberikan perlakuan berupa penambahan bumbu rasa jagung bakar. Uji ini menggunakan menggunakan hedonic test meliputi rasa, warna, aroma, tekstur dan kerenyahan. Daftar pertanyaan diajukan kepada 31 panelis menggunakan scoring method yang dinyatakan dalam skor 1-5 dengan rincian; 1 (sangat tidak suka), 2 (tidak suka), 3 (kurang suka), 4 (suka), 5 (sangat suka).

\section{Analisis Statistik}

Analisis statistik pada sifat kimia dan fisik dilakukan dengan membandingkan produk formulasi dengan produk pasaran merek Oishi. Dilakukan uji-t ( $t$-test) dengan selang kepercayaan $5 \%$ menggunakan independent sample $t$-test. Data hasil uji organoleptik dianalisis dengan menggunakan uji statistik General Linear Models Univariate. Uji statistik ini dilakukan dengan aplikasi SPSS 16.0.

\section{HASIL DAN PEMBAHASAN}

\section{Karakteristik Kimia Bahan Baku}

Tabel 1. Hasil Kandungan Nutrisi Bahan Baku per $100 \mathrm{~g}$

\begin{tabular}{|c|c|c|c|c|c|c|c|c|c|}
\hline \multirow{3}{*}{ Nutrisi } & \multicolumn{3}{|c|}{ Grits Jagung } & \multicolumn{3}{|c|}{ Kecambah Kacang Tunggak } & \multicolumn{3}{|c|}{ Grits Kecambah Kacang Kecipir } \\
\hline & \multicolumn{2}{|c|}{ Analisis } & \multirow[t]{2}{*}{ Pustaka ${ }^{1}$} & \multicolumn{2}{|c|}{ Analisis } & \multirow[t]{2}{*}{ Pustaka } & \multicolumn{2}{|c|}{ Analisis } & \multirow[t]{2}{*}{$\begin{array}{l}\text { Kacang } \\
\text { Kecipir }\end{array}$} \\
\hline & BB & BK & & BB & BK & & BB & BK & \\
\hline Air $(g)$ & 15.12 & - & 10.00 & 5.55 & - & $5.36^{3}$ & 6.35 & - & $6.47^{4}$ \\
\hline Protein $(\mathrm{g})$ & $5.14 \pm 0.00$ & 6.05 & 8.80 & $31.75 \pm 0.35$ & 33.62 & $29.06^{2}$ & $44.78 \pm 1.35$ & 47.82 & $43.04^{4}$ \\
\hline Lemak $(\mathrm{g})$ & $5.51 \pm 0.15$ & 6.49 & 1.20 & $2.96 \pm 0.91$ & 3.13 & $3.71^{2}$ & $19.63 \pm 1.38$ & 20.96 & $24.91^{4}$ \\
\hline Karbohidrat (g) & $73.33 \pm 0.02$ & 86.39 & 76.90 & $55.63 \pm 1.42$ & 58.90 & $50.20^{2}$ & $25.98 \pm 2.77$ & 27.74 & $21.83^{4}$ \\
\hline Kadar Abu (g) & $0.91 \pm 0.01$ & 1.07 & - & $4.11 \pm 0.10$ & 4.35 & $3.38^{2}$ & $3.26 \pm 0.07$ & 3.48 & $3.76^{4}$ \\
\hline Kalori (kkal) & $363.44 \pm 1.37$ & 428.17 & 371.00 & $376.11 \pm 3.69$ & 398.24 & - & $\begin{array}{c}459.70 \pm \\
6.12\end{array}$ & 490.88 & $409.00^{5}$ \\
\hline
\end{tabular}

Sumber: ${ }^{1}$ USDA (2016), ${ }^{2}$ Ismayanti (2014), ${ }^{3}$ Febriyanty (2014), ${ }^{4}$ Putri (2010), ${ }^{5}$ USDA (2016)

Tabel 1 menunjukkan bahwa ketiga bahan yang digunakan mengandung karbohidrat yang tinggi serta kadar air dan lemak yang rendah, sesuai dengan karakteristik bahan baku untuk proses ekstrusi. Kadar karbohidrat pada suatu bahan pangan bergantung pada kadar pati yang terkandung di dalamnya. Total karbohidrat sangat berpengaruh terhadap proses ekstrusi dikarenakan berperan dalam pengembangan dan pembentukan tekstur produk akhir ekstrudat. Kadar air pada bahan baku ekstrusi diatur menjadi 14-15\% agar menghasilkan produk yang mengembang secara maksimal (Moscicki, 2011). Kandungan lemak pada bahan baku harus diperhatikan. Penggunaan lemak $>5 \%$ dapat menurunkan tingkat pengembangan produk ekstrudat dikarenakan lemak dapat menurunkan daya putar selama proses ekstrusi di dalam 
barel sehingga tidak tercukupinya tekanan untuk pengembangan produk (Singh et al., 2007). Penggunaan bahan tinggi protein dapat menghasilkan produk yang lebih baik nutrisinya. Protein tidak terlalu berpengaruh terhadap karakteristik fisik produk akhir.

\section{Penentuan Formula Ekstrudat (Model Matematis)}

Berdasarkan hasil analisis pada Tabel 1, selanjutnya ditentukan model matematis yang akan dimasukkan ke dalam aplikasi Solver. Model matematis yang digunakan ditunjukkan pada Tabel 2. Model matematis ini meliputi parameter dan batasan yang digunakan untuk menghasilkan produk akhir yang diinginkan, yaitu protein minimal $30 \%$ dan kalori minimal $20 \%$ AKG anak sia 7-9 tahun.

Tabel 2. Model matematis formula produk ekstrudat

\begin{tabular}{|c|c|}
\hline Fungsi & Persamaan \\
\hline Maksimalisasi kalori & Zmaks $=4.2817 \mathrm{X} 1+3.9824 \mathrm{X} 2+4.9088 \mathrm{X} 3$ \\
\hline Pembatas kalori & $4.2817 X 1+3.9824 X 2+4.9088 X 3 \geq 370 \mathrm{kkal}$ \\
\hline Pembatas protein & $0.0605 \times 1+0.3362 X 2+0.4782 X 3 \geq 14.70 \mathrm{~g}$ \\
\hline Total berat & $\mathrm{X} 1+\mathrm{X} 2+\mathrm{X} 3=100 \mathrm{~g}$ \\
\hline $\begin{array}{l}\text { Jumlah kecambah kacang tunggak } \\
\text { minimal } 25 \mathrm{~g}\end{array}$ & $X 2 \geq 25 \mathrm{~g}$ \\
\hline $\begin{array}{l}\text { Jumlah kecambah kacang kecipir } \\
\text { maksimal } 5 \mathrm{~g}\end{array}$ & $\mathrm{X} 3 \leq 5 \mathrm{~g}$ \\
\hline
\end{tabular}

Setelah diolah oleh Microsoft Excel 2010, diperoleh formulasi terbaik untuk mencapai produk akhir ekstrudat jagung : kecambah kacang tunggak : kecambah kacang kecipir yang diinginkan yaitu 70:25:5. Formulasi ini dilanjutkan pada proses produksi menjadi ekstrudat yang ditunjukkan pada Gambar 1.

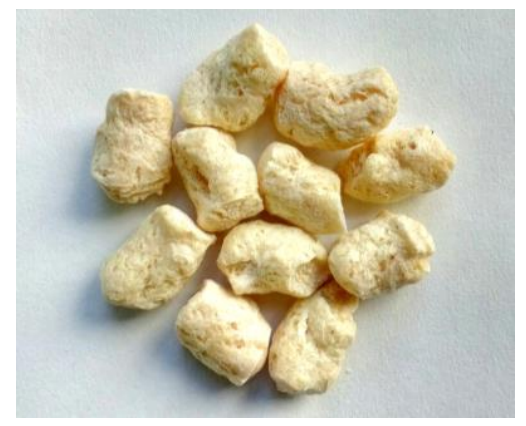

Gambar 1. Produk EKstrudat Formulasi 
Pengembangan Snack Ekstrusi Berbasis Jagung - Nasir, dkk Jurnal Pangan dan Agroindustri Vol.6 No.2: 74-85, April 2018

\section{Analisis Kimia}

Tabel 3. Hasil Kandungan Kimia Produk Ekstrudat per $100 \mathrm{~g}$

\begin{tabular}{ccccc}
\hline Nutrisi & Formulasi & $\begin{array}{c}\text { Komersial } \\
\text { Oishi }\end{array}$ & $\begin{array}{c}\text { Notasi } \\
\text { Uji-t 5\% }\end{array}$ & $\begin{array}{c}\text { Prediksi Linear } \\
\text { Program }\end{array}$ \\
\hline Air $(\mathrm{g})$ & $2.77 \pm 0.36$ & - & - & - \\
\hline Protein $(\mathrm{g})$ & $15.98 \pm 0.05$ & 7.14 & $\mathrm{~b}$ & 15.03 \\
\hline Lemak $(\mathrm{g})$ & $3.41 \pm 0.26$ & 25.00 & $\mathrm{~b}$ & 6.37 \\
\hline Karbohidrat $(\mathrm{g})$ & $76.43 \pm 0.49$ & 64.29 & $\mathrm{~b}$ & 76.59 \\
\hline Kadar Abu (g) & $1.42 \pm 0.43$ & - & - & - \\
\hline Kalori (kkal) & $386.01 \pm 3.75$ & 500 & $\mathrm{~b}$ & 423.82 \\
\hline \multicolumn{5}{c}{ Kumber: kandungan nutrisi pada label kemasan } \\
Kji-t 5\% dilakukan antara ekstrudat formulasi dengan ekstrudat komersial Oishi
\end{tabular}

Hasil analisis kandungan kalori dari ekstrudat formulasi adalah $386.01 \mathrm{kkal} / 100 \mathrm{~g}$ (Tabel 3). Hasil analisis kandungan kalori ekstrudat formulasi berbeda jauh dengan prediksi total kalori dari linear program dikarenakan adanya perbedaan pada kandungan lemak, dimana lemak menyumbangkan kalori yang cukup tinggi, yaitu $9 \mathrm{kkal} / \mathrm{g}$. Berdasarkan analisis statistik uji $\mathrm{T}(t-$ test), diperoleh hasil bahwa terdapat perbedaan antara kandungan kalori ekstrudat formulasi dengan kandungan kalori ekstrudat komersial merk Oishi. Namun, kandungan kalori pada ekstrudat formulasi dapat memenuhi $20.87 \%$ dari kebutuhan kalori harian untuk anak usia sekolah 7-9 tahun, yaitu $370 \mathrm{kkal}$. Sisa kalori yang belum terpenuhi dapat diperoleh dengan konsumsi makanan lainnya.

Hasil analisis kandungan protein ekstrudat formulasi adalah $15.98 \mathrm{~g} / 100 \mathrm{~g}$ (Tabel 3), sedikit lebih tinggi bila dibandingkan dengan kandungan protein prediksi linear program. Berdasarkan analisis statistik uji T ( $t$-test), diperoleh hasil bahwa terdapat perbedaan antara kandungan protein ekstrudat formulasi dengan kandungan protein ekstrudat komersial merk Oishi. Kandungan protein ekstrudat formulasi dapat memenuhi 32.61\% kebutuhan protein harian anak usia awal sekolah 7-9 tahun, yaitu 49 kkal. Selama proses ekstrusi, protein mengalami denaturasi dan perubahan sifat dari larut air menjadi tak larut air. Proses ini terjadi pada saat suhu $60-70^{\circ} \mathrm{C}$ (Huber, 2001). Protein yang terkandung pada kacang-kacangan dapat menyerap air yang berkaitan dengan adanya gugus-gugus polar rantai samping seperti karbonil, hidroksil, amino, karboksil, dan sulfhidril yang dapat menyebabkan protein dapat membentuk ikatan hydrogen dengan air karena bersifat hidrofilik (Utami dan Widyaningsih, 2015). Selain itu, proses denaturasi menyebabkan struktur kompleks protein terurai yang disebabkan adanya kadar air dan panas. Perubahan struktur protein yang menjadi lebih sederhana dapat meningkatkan daya cerna protein di dalam tubuh. Selain itu, terjadinya inaktivasi anti nutrisi yang dapat menghambat penyerapan protein juga dapat meningkatkan daya cerna protein (Ajita dan Jha, 2017).

Lemak. Hasil analisis kandungan lemak ekstrudat formulasi lebih rendah dibandingkan kandungan lemak prediksi linear program. Perbedaan yang terjadi dapat dikarenakan adanya lemak yang hilang setelah adonan keluar dari die sebagai lemak bebas (Singh et al., 2007). Selain itu, dapat juga terjadinya pembentukan senyawa komples antara lemak dengan amilosa atau protein (Camire, 2000 dalam Singh, et al., 2007; Hagenimana et al., 2006 dalam Gui, 2014). Berdasarkan analisis statistik uji T ( $t$-test), diperoleh hasil bahwa terdapat perbedaan antara kandungan lemak ekstrudat formulasi dengan kandungan lemak ekstrudat komersial merk Oishi. Kandungan lemak pada ekstrudat formulasi juga telah memenuhi syarat dari SNI untuk makanan ringan ekstrudat yaitu kandungan lemak maksimal 30\% untuk ekstrudat tanpa penggorengan dan 
$38 \%$ untuk ekstrudat dengan penggorengan, sedangkan pada ekstrudat formulasi kandungan lemak yang diperoleh kurang dari batas yang disyaratkan tersebut. Lemak berperan sebagai pelumas (lubricant) dalam proses ekstrusi karena dapat mengurangi gaya gesek antara screw dan barel dengan adonan (Guy, 2001 dalam Budi et al., 2013). Pada suhu diatas $40^{\circ} \mathrm{C}$ di dalam ekstruder, viskositas lemak akan menurun sehingga dapat tercampur dengan bahan-bahan lain dan terdispersi dengan cepat (Budi et al., 2013).

Karbohidrat. Hasil analisis kandungan karbohidrat ekstrudat formulasi tidak jauh berbeda dengan prediksi linear program. Berdasarkan analisis statistik uji T ( $t$-test), diperoleh hasil bahwa terdapat perbedaan antara kandungan karbohidrat ekstrudat formulasi dengan kandungan karbohidrat ekstrudat komersial merk Oishi. Kandungan karbohidrat terutama pati berperan penting dalam pembentukan struktur dan bentuk dari produk ekstrudat. Hal ini bergantung pada kadar amilosa dan amilopektin pada pati. Selama proses ekstrusi, terjadi gelatinisasi pati (Huber, 2001) dan pembentukan senyawa kompleks amilosa-lipid yang tergantung pada tipe pati dan lemak yang terkandung pada bahan (Singh, et al., 2007). Proses gelatinisasi ini menjadikan bentuk pati menjadi lebih larut dalam air yang terjadi pada suhu $51-78^{\circ} \mathrm{C}$ (Huber, 2001).

Serat merupakan salah satu komponen karbohidrat yang juga diperlukan bagi kesehatan. Kacang tunggak yang mengandung serat $10.60 \mathrm{~g} / 100 \mathrm{~g}$ (USDA, 2016) dan kacang kecipir yang mengandung $25.90 \mathrm{~g} / 100 \mathrm{~g}$ (USDA, 2016) menjadikan bahan ini baik sebagai bahan baku produk sumber serat. Walaupun pada produk ekstrudat formulasi ini kecambah kacang tunggak dilepas kulitnya sehingga mengurangi sebagian besar seratnya, pada kecambah kacang kecipir tidak dilakukan mengupasan kulit sehingga menjadi penyedia sumber serat selain dari jagung. Sehingga pada produk ekstrudat formulasi ini, tidak hanya dapat diperuntukkan bagi anak usia sekolah 7-9 tahun, namun juga berpotensi bagi makanan penderita diabetes dan makanan penurut berat badan.

Kadar Air. Hasil analisis kadar air ekstrudat formulasi adalah 2.77 g/100 g. Kadar air dari ekstrudat formulasi telah memenuhi syarat SNI untuk makanan ringan ekstrudat yaitu kadar air maksimal 4\%, sedangkan kadar air ekstrudat formulasi dibawah batas yang ditetapkan tersebut. Selama proses ekstrusi berlangsung sebagaian besar air yang mendapatkan tekanan dan panas yang tinggi cendering menguap atau terperangkap di dalam matriks-matriks karbohidrat yang diperlukan untuk proses gelatinisasi pati, denaturasi protein dan pengembangan produk.

Kadar Abu. Hasil analisis kandungan lemak ekstrudat formulasi adalah $1.42 \mathrm{~g} / 100 \mathrm{~g}$ (Tabel 3). Kadar abu dapat diindikasikan sebagai kandungan mineral yang terkandung dalam suatu bahan pangan. Selama proses ekstrusi kandungan mineral pada produk akhir tidak banyak berubah. Mineral merupakan zat gizi yang stabil pada kondisi suhu maupun tekanan tinggi. Namun adanya proses ini menyebabkan meningkatnya daya serap protein di dalam tubuh. Hal ini dikarenakan proses ekstruksi dapat menurunkan senyawa-senyawa yang dapat menghambat penyerapan mineral seperti asam fitat dan tannin (Singh, et al., 2007).

Nilai Angka Kecukupan Gizi (AKG). Perhitungan AKG produk ekstrudat hasil formulasi dilakukan berdasarkan Peraturan BPOM no 9 Tahun 2015 yang mensyaratkan takaran saji bagi makanan ringan ekstrudat yaitu 20 gram dan kebutuhan kalori umum pada label pangan yaitu 2000 kkal (Tabel 4). Untuk dapat memenuhi kebutuhan harian kalori bagi anak usia 7-9 tahun, diperlukan konsumsi produk ini yaitu 23 kali. Menurut Folliard dan Duncan-Goldsmith (2013), makanan rngan/selingan harus mengandung $<200 \mathrm{kkal}$ dalam setiap takaran sajinya berdasarkan standar USDA akan standar Smart Snack in School bagi anak usia SD, SMP dan SMA. Produk ini disarankan sebagai makanan ringan atau selingan disamping makanan utama yaitu makan 
pagi, siang, dan malam. Selain dari produk ekstrudat ini, kebutuhan nutrisi lainnya dapat diperoleh dari konsumsi makanan utama tersebut serta konsumsi makanan sehat lainnya.

Tabel 4. Konversi kandungan gizi produk ekstrudat formulasi dalam takaran saji

\begin{tabular}{ccc}
\hline Kandungan Gizi & Jumlah dalam 20 g & Jumlah dalam \% AKG 2000 kkal (\%) \\
\hline Karbohidrat & $0.68 \mathrm{~g}$ & 0.76 \\
\hline Protein & $3.20 \mathrm{~g}$ & 0.16 \\
\hline Lemak & $15.29 \mathrm{~g}$ & 0.03 \\
\hline Kalori & $80.07 \mathrm{kkal}$ & 4 \\
\hline
\end{tabular}

\section{Sifat Fisik Ekstrudat}

Tabel 5. Hasil kandungan fisik produk ekstrudat per $100 \mathrm{~g}$

\begin{tabular}{|c|c|c|c|c|}
\hline \multicolumn{2}{|c|}{ Analisis } & Formulasi & Komersial Oishi & Uji-t 5\% \\
\hline \multicolumn{2}{|c|}{ Derajat Pengembangan (\%) } & $522.50 \pm 0.15$ & 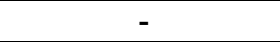 & - \\
\hline \multicolumn{2}{|c|}{ Daya Patah (N/m) } & $16.37 \pm 0.15$ & - & - \\
\hline \multicolumn{2}{|c|}{ IPA (g/ml) } & $0.03 \pm 0.01$ & $0.02 \pm 0.01$ & tb \\
\hline \multicolumn{2}{|c|}{$\mathrm{IKA}(\mathrm{g} / \mathrm{ml})$} & $0.03 \pm 0.00$ & $0.04 \pm 0.00$ & $b$ \\
\hline \multirow{3}{*}{ Warna } & $\mathrm{L}$ & $76.71 \pm 0.59$ & $81.08 \pm 0.36$ & $\mathrm{~b}$ \\
\hline & a & $3.18 \pm 0.54$ & $1.77 \pm 0.23$ & $\mathrm{~b}$ \\
\hline & $\mathrm{b}$ & $28.79 \pm 0.28$ & $39.02 \pm 0.17$ & $\mathrm{~b}$ \\
\hline
\end{tabular}

Keterangan: $\mathrm{b}=$ beda nyata, $\mathrm{tb}=$ tidak beda nyata

\section{Derajat Pengembangan}

Derajat pengembangan ekstrudat formulasi yang dihasilkan yaitu 522.50\% (Tabel 5). Rasio pengembangan ditentukan oleh kadar pati, terutama dari rasio amilosa dan amilopektin yang terkandung pada suatu produk pangan. Amilopektin mempunyai kemampuan mengembang yang lebih besar dibandingkan amilosa (Utami, 2014). Derajat pengembangan menunjukkan ukuran, jumlah dan distribusi udara di dalam produk pangan. Hal ini juga dipengaruhi oleh perbedaan tekanan pada die ekstruder dengan atmosfer. Tekanan yang tinggi akan berkurang saat bahan terlepas dari die yang menyebabkan penguapan air yang cepat sehingga produk mengembang (Mesquita et al., 2013).

\section{Daya Patah}

Daya patah pada bahan pangan menunjukkan kemampuan bahan pangan terhadap tekanan. Hal ini juga berhubungan dengan tingkat kerenyahan suatu bahan pangan. Daya patah ekstrudat formulasi menunjukkan nilai $16.37 \mathrm{~N} / \mathrm{m}$. Semakin rendah nilai daya patah yang diperoleh menunjukkan semakin baik tingkat kerenyahannya. Daya patah bergantung pada kandungan pati dan protein dalam bahan baku pembuatan suatu produk pangan. Kandungan pati, terutama tingginya kandungan amilosa dapat menghasilkan produk pangan yang lebih keras (Utami dan Widyaningsih, 2015). Selain itu, protein juga berperan dalam tingkat kekerasan suatu produk dikarenakan selama proses denaturasi dapat terjadi pengikatan kembali gugus reaktif yang jumlah ikatannya lebih banyak dan lebih kuat (Utami dan Widyaningsih, 2015)

\section{Indeks Penyerapan Air (IPA) dan Indeks Kelarutan Air (IKA)}

Indeks Penyerapan Air (IPA) merupakan salah satu indikator fungsional derajat pemasakan ekstrusi. IPA didefinisikan sebagai kemampuan suatu bahan untuk menyerap air dalam jumlah tertentu (Ajita dan Jha, 2017). Hasil uji T (t-test) menunjukkan tidak terdapat perbedaan antara nilai IPA ekstrudat formulasi dengan ekstrudat merek Oishi $(0.02 \mathrm{~g} / \mathrm{ml})$. Nilai 
IPA dalam suatu bahan dipengaruhi oleh jumlah pati yang terdekstrinisasi (Budijanto, dkk, 2012). Selama proses pemasakan, pati yang terkandung pada bahan akan mengalami gelatinisasi yang terus meningkat sehingga akan mengalami dekstrinisasi.

Indeks Kelarutan Air (IKA) menunjukkan banyaknya bahan yang dapat larut dalam air dalam jumlah tertentu (Ajita dan Jha, 2017). Pengukuran IKA pada produk ektrudat menunjukkan tingkat pemasakan suatu proses ekstrusi karena menunjukkan jumlah pati yang mengalami gelatinisasi (Budijanto, dkk, 2012). Hasil pengukuran IKA pada ekstrudat formulasi menunjukkan nilai $0.03 \mathrm{~g} / \mathrm{ml}$. Berdasarkan hasil uji $\mathrm{T}(t$-test), terdapat perbedaan antara nilai IKA ekstrudat formulasi dengan ekstrudat merek Oishi $(0,04 \mathrm{~g} / \mathrm{ml})$. Menurut Budijanto, dkk (2012), nilai IKA dipengaruhi juga oleh parameter proses seperti kelembaban dan temperature ekstrusi.

\section{Warna}

Hasil pengamatan warna ekstrudat formulasi dan ekstrudat Oishi disajikan pada Tabel 5. Uji T ( $t$-test) terhadap tingkat kecerahan $\left(\mathrm{L}^{*}\right)$, kemerahan $\left(\mathrm{a}^{*}\right)$, dan kekuningan $\left(\mathrm{b}^{*}\right)$ pada ekstrudat formulasi dan ekstrudat Oishi menunjukkan adanya perbedaan. Warna pada produk ekstrudat dipengaruhi oleh bahan baku pembuatan yang digunakan serta cara pengolahan bahan yang dilakukan. Selama proses ekstrusi, terjadi reaksi browning seperti karamelisasi, reaksi Maillard dan hilangnya beberapa pigmen yang terkandung di dalam bahan (Mesquita et al., 2013). Pada reaksi Maillard, terjadi reaksi antara gugus amino dari grits kecambah kacang tunggak dan kacang kecipir dengan gula pereduksi dari grits jagung sehingga akan terbentuk senyawa melanoidin yang menyebabkan warna ekstrudat menjadi coklat dan rasa yang sedikit pahit (Peksa et al., 2016). Warna coklat yang berlebihan dapat menyebabkan warna dan penampakan menjadi kurang menarik dan rasa yang kurang disukai masyarakat.

\section{Analisis Organoleptik}

Tabel 6. Hasil Uji Kesukaan Produk Ekstrudat

\begin{tabular}{cccccc}
\hline Sampel & Warna & Aroma & Rasa & Tekstur & Kerenyahan \\
\hline Formulasi & $3.19 \pm 1.08$ & $3.42 \pm 0.96$ & $2.94 \pm 1.15$ & $4.03 \pm 0.84$ & $4.16 \pm 0.93$ \\
\hline Formulasi + Bumbu & $3.90 \pm 1.01$ & $3.61 \pm 1.05$ & $3.87 \pm 1.02$ & $4.10 \pm 0.79$ & $4.32 \pm 0.75$ \\
\hline Komersial 1 (Momogı) & $3.90 \pm 0.87$ & $4.35 \pm 0.75$ & $4.61 \pm 0.67$ & $4.03 \pm 0.87$ & $4.06 \pm 0.85$ \\
\hline Komersial 2 (Oishı) & $4.29 \pm 0.74$ & $4.32 \pm 0.91$ & $4.52 \pm 0.81$ & $4.26 \pm 1.00$ & $4.42 \pm 0.85$ \\
\hline Keterangan: skala: 1 (sangat tidak suka), 2 (tidak suka), 3 (kurang suka), 4 (suka), 5 (sangat suka)
\end{tabular}

Berdasarkan uji GLM-Univariate dengan selang kepercayaan 5\%, terdapat perbedaan tingkat kesukaan panelis pada parameter warna, aroma dan rasa antara ekstrudat formulasi dengan ekstrudat komersial merek Oishi dan Momogi (Tabel 7). Panelis cenderung lebih menyukai ekstrudat komersial (Tabel 6). Pada ekstrudat formulasi yang ditambahi bumbu dibandingkan dengan ekstrudat komersial merek Oishi dan Momogi, juga menunjukkan adanya perbedaan tingkat kesukaan panelis pada parameter aroma dan rasa, sedangkan pada parameter warna menunjukkan tidak adanya perbedaan (Tabel 7). Hal ini membuktikan bahwa penambahan bumbu dapat meningkatkan tingkat kesukaan warna panelis terhadap produk ekstrudat. Warna pada ekstrudat formulasi yang agak kecoklatan kurang diminati oleh panelis (Tabel 6). Panelis cenderung lebih menyukai produk dengan warna yang cerah dan mencolok seperti kuning atau merah. Penggunaan kecambah kacang tunggak dan kacang kecipir menghasilkan aroma khas kacang yang cukup kuat pada produk akhir. Penambahan bumbu dapat meningkatkan tingkat kesukaan panelis pada rasa produk, walaupun tidak secara signifikan. Penggunaan bahan baku pada ekstrudat komersial yaitu jagung menghasilkan rasa jagung yang agak manis dan gurih. Rasa pada ekstrudat formulasi yang berbahan dasar 
kombinasi jagung, kecambah kacang tunggak dan kecipir memiliki rasa kacang yang cukup kuat dan meninggalkan after taste rasa pahit setelah dikonsumsi. Penambahan bumbu/perasa dapat sedikit menutupi rasa pahit tersebut sehingga dapat meningkatkan nilai kesukaan panelis.

Tabel 7. Hasil Uji GLM-Univariate Tingkat Kesukaan Produk Ekstrudat

\begin{tabular}{ccccccc}
\hline & Sampel & Warna & Aroma & Rasa & Tekstur & Kerenyahan \\
\hline \multirow{2}{*}{ Formulasi } & Komersial 1 (Momogi) & $\mathrm{b}$ & $\mathrm{b}$ & $\mathrm{b}$ & $\mathrm{tb}$ & $\mathrm{tb}$ \\
\cline { 2 - 6 } & Komersial 2 (Oishi) & $\mathrm{b}$ & $\mathrm{b}$ & $\mathrm{b}$ & $\mathrm{tb}$ & $\mathrm{tb}$ \\
\hline $\begin{array}{c}\text { Formulasi } \\
\text { Bumbu }\end{array}$ & Komersial 1 (Momogi) & $\mathrm{tb}$ & $\mathrm{b}$ & $\mathrm{b}$ & $\mathrm{tb}$ & $\mathrm{tb}$ \\
\cline { 2 - 7 } & Komersial 2 (Oishi) & $\mathrm{tb}$ & $\mathrm{b}$ & $\mathrm{b}$ & $\mathrm{tb}$ & $\mathrm{tb}$ \\
\hline
\end{tabular}

Keterangan: b: beda nyata, tb: tidak beda nyata

Pada parameter tekstur dan kerenyahan, tidak terdapat perbedaan tingkat kesukaan panelis baik ekstrudat formulasi maupun ekstrudat formulasi yang ditambahi bumbu dibandingkan dengan ekstrudat komersial merek Oishi dan Momogi. Penggunaan jagung pada semua produk menghasilkan tekstur yang disukai panelis. Adanya penambahan kecambah kacang tunggak dan kecipir pada eksrudat formulasi dan ekstrudat formulasi dengan penambahan bumbu tidak terlalu mempengaruhi tingkat kesukaan panelis terhadap tekstur dan kerenyahan produk ekstrudat.

\section{SIMPULAN}

Pengembangan produk ekstrudat berbasis jagung, kecambah kacang tunggak dan kecambah kacang kecipir dengan menggunakan linear programming menunjukkan, formulasi terbaik yaitu $70 \%$ jagung, 25\% kecambah kacang tunggak, dan 5\% kecambah kacang kecipir untuk mencapai minimal $20 \%$ kalori dan $30 \%$ protein bagi anak usia 7-9 tahun. Kandungan nutrisi produk ekstrudat formulasi yaitu kadar air $2.77 \%(\mathrm{~b} / \mathrm{b})$, protein $15.98 \%(\mathrm{~b} / \mathrm{b})$, lemak $3.41 \%(\mathrm{~b} / \mathrm{b})$, karbohidrat 76.43\% (b/b), kadar abu 1.42\% (b/b) dan kalori $386.01 \mathrm{kkal}$. Ekstrudat formulasi memiliki sifat fisik derajat pengembangan $522.50 \%$, daya patah $16.37 \mathrm{~N} / \mathrm{m}$, IPA $0.03 \mathrm{~g} / \mathrm{ml}$, IKA $0.03 \mathrm{~g} / \mathrm{ml}$, dan warna dengan nilai L 76.71, a 3.18, dan b 28.79. Uji Hedonik pada produk ekstrudat dengan skala 1-5 menunjukkan nilai warna 3.19 (kurang suka), aroma 3.42 (kurang suka), rasa 2.94 (kurang suka), tekstur 4.03 (suka) dan kerenyahan 4.16 (suka). Penambahan bumbu pada produk formulasi dapat mempengaruhi nilai kesukaan panelis terutama pada parameter warna dan dapat meningkatkan nilai kesukaan panelis pada parameter rasa.

\section{DAFTAR PUSTAKA}

Ajita, T dan S. K. Jha. 2017. Extrusion Cooking Technology: Principal Mechanism and Effect on Direct Expanded Snacks - An Overview. ISEKI-Food Association (IFA). International Journal of Food Studies Vol 6 No 1 pp 113-128

Anton, A., R. Fulcher, dan S. Arnfield. 2009. Physical and Nutritional Impact of Fortification of Corn Starch-Based Extruded Snacks with Common Bean (Phaseolus Vulgaris L.) Flour: Effects of Bean Addition and Extrusion Cooking. Jurnal Food Chemistry, Vol. 113. No. 4, pp 989-996

AOAC (Analysis of the Association of Analytical Chemists). 1995. Official Methods of Analysis of the Association of Analytical Chemists. Washington D. C

Budi, F. S., P. Hariyadi, S. Budijanto dan D. Syah. 2013. Teknologi Proses Ekstrusi untuk Membuat Beras Analog. Review. Jurnal Pangan, Vol 22 No 3 pp 263-274 
Pengembangan Snack Ekstrusi Berbasis Jagung - Nasir, dkk Jurnal Pangan dan Agroindustri Vol.6 No.2: 74-85, April 2018

Budijanto, S., A. B. Sitanggang, dan W. Murdiati. 2011. Karakterisasi Sifat Fisiko-Kimia dan Fungsional Isolat Protein Biji Kecipir (Psophocarpus tetragonolobus L.). Jurnal Teknologi dan Industri PanganVol. 22 No. 2 hal. 130-136

Estiasih, T. dan K. Ahmadi. 2009. Teknologi Pengolahan Pangan. Bumi Aksara: Jakarta

Febrianty, K. 2014. Evaluasi Nilai Gizi dan Daya Cerna Flake Berbasis Tepung Ubi Jalar Terfermentasi dengan Penambahan Tepung Kecambah Kacang Tunggak. Skripsi. Fakultas Teknologi Pertanian, Universitas Brawijaya

Folliard, J. N. dan D. M. Duncan-Goldsmith. 2013. Opportunities to Improve Snacks and Baverages in Schools. Journal of The Academy of Nutrition and Dietetics Vol 113 No 9 pp 1145-1151 doi:10.1016/j.jand.2013.07.012

Gui Y. dan G. H. Ryu. 2014. Effects of Extrusion Cooking on Physicochemical Properties of White and Red Gingseng (Powder). Journal of Gingseng Research Vol. 38 pp. 146-153. Elsevier

Huber, Gordon. 2001. Snack Foods Processing. Edited by E. W. Lusas dan L. W. Rooney. Washington DC: CRC Press

Hussain, M. A. dan A. Y. Basahy. 1998. Nutrient Composition and Amino Acid Pattern of Cowpea (Vigna unguiculata (L.) Walp, Fabaceae) Grown in the Gizan Area of Saudi Arabia. International Journal of Food Sciences and Nutrition Vol 49 pp 117-124

Ismayanti, M. 2014. Formulasi Bubuk MP ASI Berbasis Tepung Kecambah Kacang Tunggak dan Tepung Jagung dengan Metode Linear Programming. Skripsi. Jurusan Teknologi Hasil Pertanian. Fakultas Teknologi Pertanian. Universitas Brawijaya Malang

Khairi, E. dan B. Kanetro. 2014. Pengaruh Berbagai Kecambah Kacang-Kacangan terhadap Kadar Asam Amino Bebas Limbah Cair Isolasi Protein. Jurnal Agrisains Vol 5 No 2

Kosawara, S. 2009. Teknologi Pengolahan Jagung (Teori dan Praktek). Ebookpangan.com

Lingko, P., P. Colonna dan C. Mercier. 1981. HTST Extrusion Cooking. Dalam: Y. Pomeronz (Editor). Advanced in Cereal Science and Technology. The AVIAACC Inc., St. Paul. Minnesota

Mesquita, C. B., M. Leonel, M. M. Mischan. 2013. Effects of Processing on Physical Properties of Extruded Snacks with Blends of Sour Cassava Starch and Flaxseed Flour. Journal of Food Science and Technology Vol. 33 No. 3 pp. 404-410, ISSN 0101-2061

Moscicki, L. 2011. Extrusion-Cooking Techniques. Wiley-VCH : Germany

Nurmasita, S. 2014. Optimasi Pembuatan Food Bars Berbahan Dasar Tepung Ubi Jalar Ungu (Ipomoea batatas L. Varietas Ayamurasakı) dan Tepung Kecambah Kacang Gude (Cajanus cajan L.) sebagai Alternatif Pangan Darurat Menggunakan Teknik Linear Programming. Skripsi. Fakultas Teknologi Pertanian, Universitas Brawijaya

Peksa, A., A. Kita, A. A. Carbonell-Barrachina, J. Miedzianka,J. Kolniak-Ostek, A. Tajner-Czopek, E. Rytel,A. Siwek, D Miarka \& W. Drozdz. 2016. Sensory attributes and physicochemical features of corn snacks as affected by different fl our types and extrusion conditions. Journal of Food Science and Technology 72(2016) 26-36

Prakash, D., P. N. Misra dan P. S. Misra. 1987. Amino Acid Profile of Winged Bean (Psophocarpus tetragonolobus (L.) DC): A Rich Source of Vegetable Protein. Plant Foods for Human Nutrition 37 pp 261-264. Martinus Nijhoff Publishers: Netherlands

Putri, Y. U. 2010. Studi Pembuatan Tepung Biji Kecipir (Psophocarpus tetragonollbus (L) DC) dengan Metode Penggilingan Basah dan Analisis Sifat Fisiko-Kimia serta Karakteristik Fungsionalnya. Skripsi. Fakultas Teknologi Pertanian, Institut Pertanian Bogor

Rahardian, M. Y. 2015. Karakteristik Food Bars Berbasis Tepung Kecambah Kacang Tunggak (Vigna unguiculata L.) dan Tepung Ubi Jalar Ungu (Ipomoea batatas L.) (Kajian Suhu dan Lama Waktu Pemanggangan). Skripsi. Jurusan Teknologi Hasil Pertanian. Fakultas Teknologi Pertanian. Universitas Brawijaya Malang

Singh, S., S. Gamlath dan L. Wakeling. 2007. Nutritional Aspects of Food Extrusion: A Review. International Journal of Food Science and Technology Vol 42 pp 916-929 
USDA, 2016. USDA National Nutrient Database for Standard Reference: Basic Report 11595, Winged Beans, Mature Seeds, Raw. www.ndb.nal.usda.gov/ndb/ Diunduh pada tanggal 27 Juni 2016

USDA, 2016. USDA National Nutrient Database for Standard Reference: Basic Report 16108, Soybeans, Mature Seeds, Raw. www.ndb.nal.usda.gov/ndb/ Diunduh pada tanggal 14 Juli 2016 pukul 00.21 WIB

Utami, D. 2014. Evaluasi Nilai Gizi dan Daya Cerna secara In Vitro Snack Ekstrudat Ubi Jalar Oranye Tersuplementasi Tempe Kacang Tunggak. Skripsi. Jurusan Teknologi Hasil Pertanian. Fakultas Teknologi Pertanian. Universitas Brawijaya Malang

Utami, D. dan T. D. Widyaningsih. 2015. Pengembangan Snack Ekstrudat Berbasis Ubi Jalar Oranye Tersubstitusi Tempe Kacang Tunggak sebagai Sumber Protein. Jurnal Pangan dan Agroindustri Vol 3 No 2 pp 620-630 